\title{
Moral and Religious Values in the Novel "Negeri Lima Menara" by A. Fuadi and its Relationship as Reading Materials in Schools Year 2020/2021
}

\author{
Putri Apriani $^{1}$, Erikson Saragih ${ }^{2}$, Rosliani $^{3}$ \\ 1,2Universitas Prima Indonesia \\ ${ }^{3}$ Balai Bahasa Sumatera Utara \\ Email: putriapriani343@gmail.com, erikson.saragih@gmail.com,rosliani.12@gmail.com
}

\begin{abstract}
This study aims to describe the moral values and religious values in the novel Negeri Lima Menara in the development of learning, as well as to describe the relevance of moral and religious values in Negeri Lima Menara as student reading material. The method used in this research is qualitative descriptive analytical method, which is to provide an understanding of the elements that are the center of the research so as to achieve the expected results in the Negeri Lima Menara Novel by A. Fuadi. The results showed that moral values consisted of 6 categories, namely honesty with a frequency of 13 or $21.311 \%$, authentic values (confidence) with a frequency of 15 or $24.590 \%$, willingness to be responsible with a frequency of 14 or $22.950 \%$, moral independence with a frequency of 7 or $11,475 \%$, moral courage with a frequency of 8 or $13,114 \%$ and humility with a frequency of 4 or $9,677 \%$. Meanwhile, the religious values in the Negeri Lima Menara novel by A. Fuadi consist of 6 categories, namely submission and obedience with a frequency of 7 or $24.137 \%$, a life full of deference with a frequency of 7 or $24.137 \%$, inner feelings related to God with a frequency of 5 or $17,241 \%$, feelings of sin with a frequency of 5 or $17,241 \%$, feelings of fear with a frequency of 2 or $6,896 \%$ and acknowledging the greatness of God with a frequency of 5 or $17,241 \%$.
\end{abstract}

Keywords: moral value; religious value; the Negeri Lima Menara novel

\section{Introduction}

Literary work is something that is produced by humans and is communicated to produce aesthetic values. In creating literary works, the author does not only carve aesthetic values but also conveys messages, moral values and goodness. Moral values conveyed in literary works are in order to educate humans in all aspects or problems of life and life so that they can regulate their behavior to become a good human being. According to Nurgiyantoro (1998: 323-324) (in Hasanah, 2017: 117-118) the types and forms of moral values in literary works vary, depending on the wishes, beliefs, and interests of the author so that the types and forms of these moral values can cover all the problems of life. and moral life about human relations, as well as human relations with the environment. So, moral values are various types and forms of moral values that are educational; whether in the form of religious morals (human relations with God), social morals (human relations with others, including himself), or moral maintenance and preservation of nature (human relations with the natural environment). Meanwhile, religious value in literary works is very necessary because literary works grow from a religious society. With the existence of religious values, it can provide inner awareness to create goodness, and it is necessary to instill awareness of understanding and appreciation of religious values, especially in the current era of globalization, a work of fiction in the form of novels that have religious values is needed as a building of faith. According to Suseno (1987: 142) attitudes and actions related to moral values, namely: 
1. Honesty self).

Being honest with others means we always appear as ourselves (we deserve our inner

2. Be fair (reasonable)

Namely behaving but not acting contrary to their conscience and beliefs. The harmony based on falsehood, injustice and lies will tear.

3. Authentic Values

Authentic human is a human who lives, shows himself according to his authenticity, with actual personality.

4. Willingness to be Responsible

Namely (1) willingness to do whatever is best possible. (2) Responsible means attitude towards tasks that burden us and overcome all ethical regulations. (3) The insight of a person who is willing to be responsible in principle is not limited, that is, it does not limit his attention to what is his affairs and obligations, but is responsible when needed. (4) Willingness to be responsible includes willingness to be asked for and to give, to be responsible for actions, to carry out duties and obligations

5. Moral Independence

Morally independent means that we cannot be bought by the majority, that we will never get along just for the sake of togetherness if that harmony violates justice

6. Moral Courage

Moral courage means siding with the weaker against the strong, who treat him unfairly. 7. Humility

Humility is the inner strength to see oneself according to reality.

Astuti (2019) states that his possibility is caused by many factors, including the fictional stories taken from folklore often present events, characters and bad attitudes as a comparison for good characters, but do not achieve completeness. So what is meant by moral education is guidance, care and assistance from adults to bring students to maturity that can familiarize themselves with the qualities that are praiseworthy or easy and avoid traits that are despicable or advanced (Haidir, 2020).

\section{Research Method}

This research was conducted with a qualitative approach that examines the Negeri Lima Menara novel. Qualitative research (Meoleong, 2011: 6) is a research that intends to understand the phenomena of what is experienced by research subjects such as behavior, perceptions, motivation, actions and others holistically. and by means of description in the form of words and language, in a specific context which is natural and by making use of various scientific methods. The method used in this research is qualitative descriptive analytical method. Sugiyono (2005: 21) states that the descriptive method is a method used to describe or analyze a research result but is not used to make broader conclusions. The subject of this research is the Negeri Lima Menara novel by A. Fuadi.

\section{Discussion}

\subsection{Moral Values in the Negeri Lima Menara Novel by Ahmad. Fuadi}

The description of moral values in the Negeri Lima Menara novel By A. Fuadi consists of 6 categories, namely as presented in the following table form: 
Tabel 1. Moral Values

\begin{tabular}{|r|c|c|c|c|}
\hline \multirow{2}{*}{ No. } & Moral values & Novel Page Numbers & \multicolumn{2}{|c|}{ Total } \\
\cline { 3 - 5 } & Honesty & $\begin{array}{c}3,12,29,45,66,121,139,187, \\
188,261,284,309,405\end{array}$ & 13 & 21,311 \\
\hline 1. & $\begin{array}{c}\text { Authentic value } \\
\text { (self-confidence) }\end{array}$ & $\begin{array}{c}8,50,83,84,99,136,158,159, \\
172,213,282,318,327,330,336\end{array}$ & 15 & 24,590 \\
\hline 3. & $\begin{array}{c}\text { Willingness to take } \\
\text { responsibility }\end{array}$ & $\begin{array}{c}14,44,45,47,56,57,67,86,94, \\
113,219,245,327,361\end{array}$ & 14 & 22,950 \\
\hline 4. & Moral independence & $6,85,152,228,270,362,398$ & 7 & 11,475 \\
\hline 5. & Moral courage & $13,50,65,69,74,91,267,307$ & 8 & 13,114 \\
\hline 6. & Modesty & $269,284,291,295$ & 4 & 6,557 \\
\hline \multicolumn{7}{|r}{ TOTAL } & 61 & $100 \%$ \\
\hline
\end{tabular}

Table 1 above shows that in Negeri Lima Menara Novel, there are moral values which consist of 6 aspects, namely honesty 13 pieces (21.311\%), authentic values (self-confidence) 15 pieces $(24.590 \%), 14$ pieces of responsibility $(22.950 \%)), 7$ pieces of moral independence $(11.475 \%), 8$ pieces of moral courage $(13.114 \%)$ and 4 pieces of humility $(9.677 \%)$. The results of the study describe the moral values of the novel in the following table form:

Table 2. Moral Values in Negeri Lima Menara Novel By A. Fuadi

\begin{tabular}{|c|c|c|c|}
\hline No. & Category & Concept & Description \\
\hline 1 & Honesty & $\begin{array}{l}\text { "Behavior is based on an } \\
\text { effort to make himself a } \\
\text { person who can always be } \\
\text { trusted in words, actions } \\
\text { and work (Wibowo, 2013: } \\
\text { 83). } \\
\text { Being honest is a } \\
\text { commendable attitude and } \\
\text { shows one's good morals } \\
\text { towards others through } \\
\text { speech acts. So the basis of } \\
\text { every effort to become a } \\
\text { person morally is honesty. } \\
\text { Without honesty, any other } \\
\text { moral virtue will lose its } \\
\text { value." }\end{array}$ & $\begin{array}{l}\text { 1. "Sorry, this is Alif from PM?" My } \\
\text { fingers quickly pressed the keys. } \\
\text { "Right. Who is this, huh?" Pause } \\
\text { for a moment. A new message } \\
\text { appeared again. "Alif members of } \\
\text { the troops. Sahibul shouted ?. My } \\
\text { heart started beating faster. My } \\
\text { fingers dance on the key-bord. } \\
\text { "Right, who is this ?!" getting } \\
\text { impatientreplief by me. "The } \\
\text { fourth tower, remember or not?" } \\
\text { (Pg } 3 \text { ) } \\
\text { "Amak, if you have to go to a } \\
\text { religious school, ambo wants to go } \\
\text { to a hut in Java, not in Bukittinggi } \\
\text { or Padang." (P. 12) } \\
\text { 3. Yes, what exactly am I looking for? } \\
\text { Just because you rebelled you } \\
\text { shouldn't enter high school? And } \\
\text { more importantly, can I survive? } \\
\text { (Pg } 29 \text { ) } \\
\text { 4. When I was in high school I was a } \\
\text { bad boy, now I am converted and } \\
\text { want to learn religion, "he said, } \\
\text { smiling broadly (Pg } 45 \text { ) } \\
\text { 5. Sorry .. sorry .... sis, we were late. } \\
\text { but only a little sis, just } 5 \text { minutes. } \\
\text { Having to carry this heavy }\end{array}$ \\
\hline
\end{tabular}




\begin{tabular}{|c|c|c|c|}
\hline & & & $\begin{array}{l}\text { wardrobe from the field. (P. 66) } \\
\text { 6. "Sorry sis. I lost my coupon. " } \\
\text { "Brother, you already know the } \\
\text { rules, right? No coupons, no } \\
\text { rendang. " } P g \text { 121) } \\
\text { 7. Only Amak himself dared to raise } \\
\text { his hand and said "we are } \\
\text { educators here and this is not } \\
\text { educational. Where our faces are } \\
\text { hidden from the All-Seeing Allah. } \\
\text { (Pg 139) } \\
\text { 8. Dul, you have done what's best for } \\
\text { the Icuk people and this country, } \\
\text { "I said while clutching his tense } \\
\text { shoulders. (Pg } 187 \text { ) } \\
\text { 9. "Well, at that time I said that I was } \\
\text { amazed at the game, I said," Ustadz } \\
\text { is very similar to Icuk and smes } \\
\text { you look like Liem Swie King". He } \\
\text { shook his head uncertainly. Then I } \\
\text { challenge, if you don't believe we } \\
\text { will watch the live broadcast } \\
\text { tomorrow night". (Pg 188) } \\
\text { 10. "I also have a friend from } \\
\text { Maninjau studying in Egypt, his } \\
\text { name is Gindo Maranjo." Masya } \\
\text { Allah, Mr. Etek Gindo is my uncle, } \\
\text { "Ustadף!" I replied surprised and } \\
\text { happy. (Pg 261) } \\
\text { 11. }\end{array}$ \\
\hline 2 & $\begin{array}{l}\text { Authentic } \\
\text { Values (self- } \\
\text { confidence) }\end{array}$ & $\begin{array}{l}\text { Living, showing himself } \\
\text { according to his } \\
\text { authenticity, with the real } \\
\text { personality }\end{array}$ & $\begin{array}{l}\text { 1. "Amak wants my son to be a great } \\
\text { religious leader with extensive } \\
\text { knowledge. Like Buya Hamka who } \\
\text { is in our village. (P. 8) } \\
\text { 2. My children. Starting from today, it } \\
\text { is the intention in your heart that } \\
\text { you intend to study only because } \\
\text { of Allah, lillabi taala. Want to prove } \\
\text { your intentions? (P. 50) } \\
\text { 3. Yes, thank you, Allah, I said, } \\
\text { clenching my hands in the air. And } \\
\text { with my chest led I walked to the } \\
\text { central security office to surrender } \\
\text { the results of my mission and } \\
\text { reclaim my independence (p. 83) } \\
\text { 4. Once everything feels right, I begin } \\
\text { to roll the end of the sarong from } \\
\text { the top to the level of my navel. } \\
\text { For a moment, I checked again } \\
\text { that everything was neat and }\end{array}$ \\
\hline
\end{tabular}




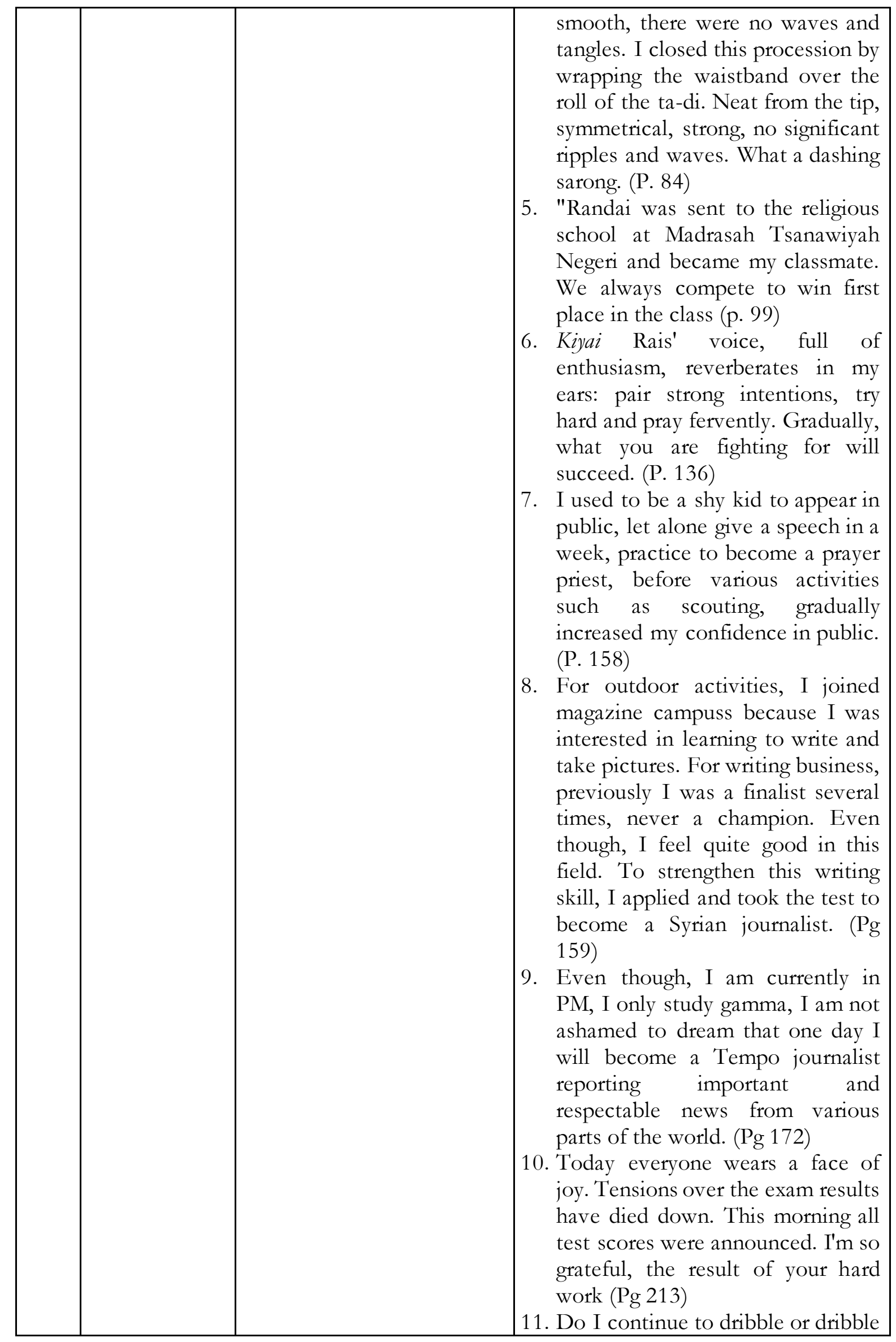




\begin{tabular}{|c|c|c|c|}
\hline & & & $\begin{array}{l}\text { back? Can he be tricked by this } \\
\text { trick? Never mind, don't analyze } \\
\text { too much, I told myself. Do } \\
\text { something! (Pg 282) } \\
\text { 12. Kiyai, the Ambassador, and the } \\
\text { audience, stretching their necks, } \\
\text { trying to catch my face, this all } \\
\text { adds to nervousness. (P. 318) } \\
\text { 13. Although this first edition is not } \\
\text { neat, it is really nice to see the } \\
\text { students scrambling to read and } \\
\text { see the photos we made. (P. } 327) \\
\text { 14. "ASSALAMUALAIKUM PAK } \\
\text { PANGLIMA!" Shocked by my } \\
\text { anchovies, he looked down at me } \\
\text { in amazement. (P. 330) } \\
\text { 15. Ustadz Salman then walked } \\
\text { away with his biggest smile ever } \\
\text { and his hand waved to us who } \\
\text { cheered triumphantly. (P. 336) }\end{array}$ \\
\hline 3 & $\begin{array}{l}\text { Willingness to } \\
\text { take } \\
\text { responsibility }\end{array}$ & $\begin{array}{l}\text { Attitudes and behavior of a } \\
\text { person to carry out the } \\
\text { duties and obligations that } \\
\text { he does for himself, society, } \\
\text { the environment, especially } \\
\text { the creator. }\end{array}$ & $\begin{array}{l}\text { 1. "Have a good time overseas, son. } \\
\text { Amak believes that this is a journey } \\
\text { to defend religion, learning } \\
\text { religious knowledge is the same as } \\
\text { jihad in Allah's path. (Pg 14) } \\
\text { 2. He gallantly said, "I want to be an } \\
\text { intellectual scholar, Ustadz. Of the } \\
\text { ten siblings, I myself was given the } \\
\text { mandate from my mother and } \\
\text { father to study religion. " (Pg 44) } \\
\text { 3. Because of that we unanimously } \\
\text { chose him to be class president. } \\
\text { Over the next year, he always } \\
\text { answered our complaints with a } \\
\text { smile that inflames our spirits. (Pg } \\
\text { 45) } \\
\text { 4. Studying here is not relaxing. So, } \\
\text { intend to walk to the limit and sail } \\
\text { to the island. Try to give a } \\
\text { complete experiment. } \\
\text { 5. From this moment on, you are } \\
\text { officially in the rules and discipline } \\
\text { of the PM. The rules will be strictly } \\
\text { enforced. Legal certainty as } \\
\text { commander. (Pg 56) } \\
\text { 6. Of course we congregate in the } \\
\text { mosque, but only Mahgrib. The rest } \\
\text { we do in the room, because that is } \\
\text { also part of education. Each } \\
\text { person will have a turn to become }\end{array}$ \\
\hline
\end{tabular}




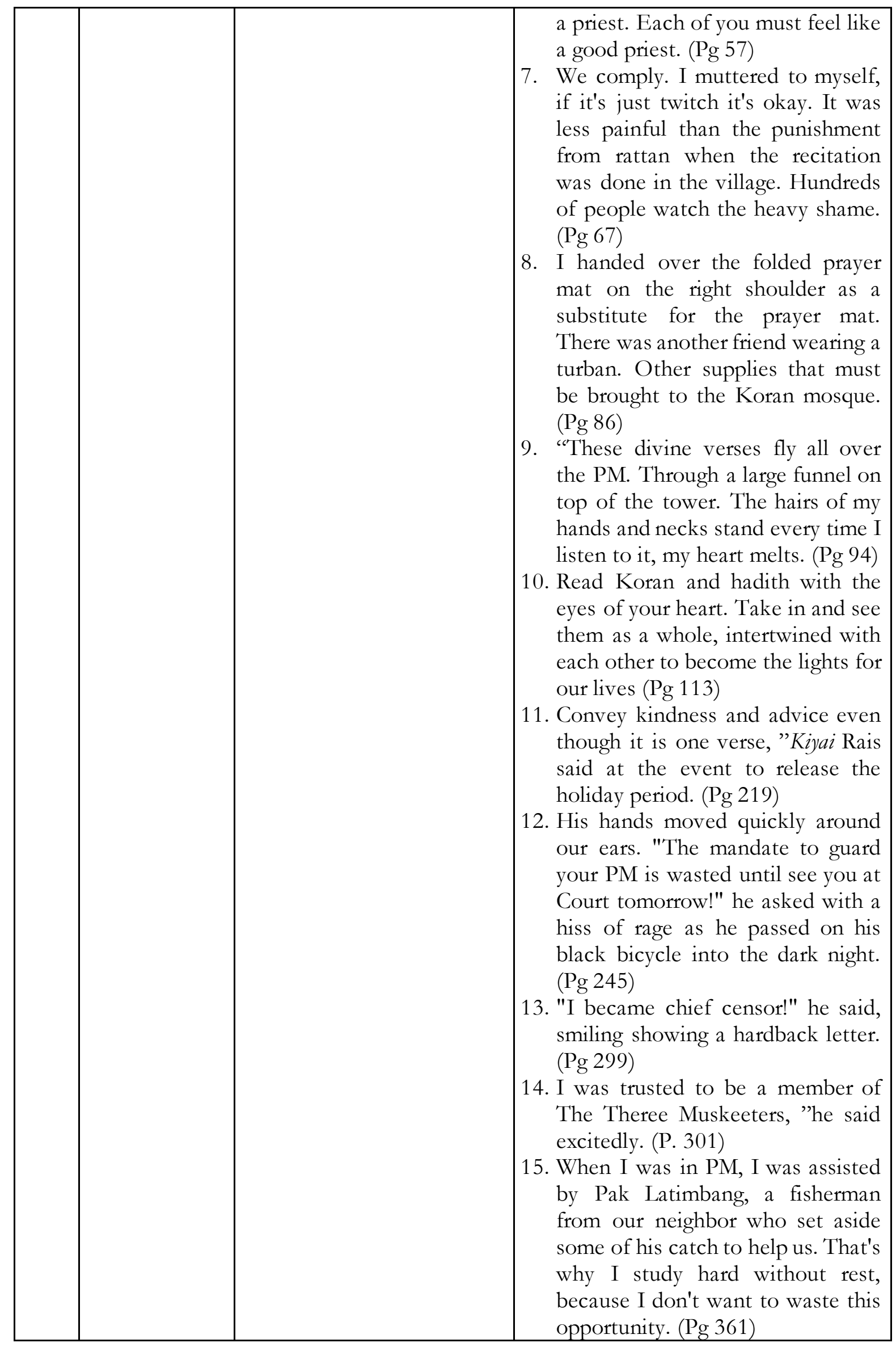




\begin{tabular}{|c|c|c|c|}
\hline 4 & $\begin{array}{c}\text { Moral } \\
\text { independence }\end{array}$ & $\begin{array}{l}\text { The attitude of getting } \\
\text { along and creating peace } \\
\text { together. }\end{array}$ & $\begin{array}{l}\text { 1. "Unusually, tonight Amak doesn't } \\
\text { flash a smile. He took off his } \\
\text { glasses and wiped the double focus } \\
\text { lens with the hem of his sleeve. } \\
\text { Amak is looking straight at me. His } \\
\text { gaze seemed to pass through my } \\
\text { minus glasses and straight through } \\
\text { to my soul. (Pg 6) } \\
\text { 2. Time to leave for PM. Amak loads } \\
\text { my four gloves. He believes that } \\
\text { the child cottage is identical to a } \\
\text { sarong that you don't use in your } \\
\text { bag as often as you and I imagine. } \\
\text { (Pg 85) } \\
\text { 3. Lif, try to hold the breath in the } \\
\text { stomach, and release as if a sound } \\
\text { from the stomach. Guaranteed } \\
\text { louder voice. He said while } \\
\text { demonstrating. (Pg } 152 \text { ) } \\
\text { 4. Welcome friends, come on where } \\
\text { your gifts for me have been } \\
\text { guarding your room for two weeks. } \\
\text { (Pg 228) } \\
\text { My roommates shouted loudly, } \\
\text { they immediately rushed in with } \\
\text { empty plates stretched out towards } \\
\text { me. One piece of rendang for one } \\
\text { person. (Pg } 270 \text { ) } \\
\text { 6. I was wondering when I should } \\
\text { make the decision to take care of } \\
\text { Grandma and go home, maybe } \\
\text { forever..."(Pg } 362 \text { ) } \\
\text { 7. We are, the sabibul of the tower, } \\
\text { huddled together. Living full of joy } \\
\text { and sorrow for } 4 \text { years at PM has } \\
\text { bonded us all in an experience and } \\
\text { brotherhood that will last a time. } \\
\text { (Pg } 398 \text { ) }\end{array}$ \\
\hline 5 & $\begin{array}{c}\text { Moral } \\
\text { Courage. }\end{array}$ & $\begin{array}{l}\text { Siding with the truth helps } \\
\text { the weak. }\end{array}$ & $\begin{array}{l}\text { 1. "Well," my voice said firmly. } \\
\text { "Think again carefully," said Amak } \\
\text { while not blinking "it's done," I } \\
\text { said repeating the same answer. (Pg } \\
\text { 13) } \\
\text { 2. He has been doing this for decades } \\
\text { and always proves he is right, as } \\
\text { long as we follow his rules, } \\
\text { "whispered the king. (Pg 50) } \\
\text { 3. Qif yes brother.... ALL OF YOU } \\
\text { STOP, a huge sound of thunder }\end{array}$ \\
\hline
\end{tabular}




\begin{tabular}{|c|c|c|c|}
\hline & & & $\begin{array}{l}\text { made us stunned. It felt like the } \\
\text { blood had receded from my face. } \\
\text { Drizzle getting closer. The dusk } \\
\text { was getting darker. (Pg 65) } \\
\text { 4. With our ears still flaring up and } \\
\text { down, we hurriedly changed our } \\
\text { prayer clothes and ran to our } \\
\text { mosque. At our mosque, every } \\
\text { evening } 3 \text { thousand students gather } \\
\text { to greet the Mahgrib call to prayer. } \\
\text { (Pg 69) } \\
\text { 5. "Please accept this punishment } \\
\text { sincerely as part of education," this } \\
\text { time his voice was made low but } \\
\text { threatening. (Pg 74) } \\
\text { 6. Marosok culture. Fingering under } \\
\text { the scabbard. Bargaining by using } \\
\text { gestures, eh?" (Pg } 91 \text { ) } \\
\text { 7. The writing will be: "Nous sommes } \\
\text { la grande famille de la classe 1B Pondok } \\
\text { Madani, Indonesie". That means, we } \\
\text { are the big family of class } 1 \mathrm{~B} \text {. "He } \\
\text { wrote these strange sounding } \\
\text { words on the blackboard. (Pg 267) } \\
\text { 8. Now, Baso Salahudin and Raja } \\
\text { Lubis's "Arabic-English- } \\
\text { Indonesian Student Dictionary" is } \\
\text { available in our bookstore (page } \\
\text { 307). }\end{array}$ \\
\hline 6 & Modesty & $\begin{array}{c}\text { Be grateful for everything } \\
\text { he has }\end{array}$ & $\begin{array}{l}\text { 1. "Huh, praying wasel, but under the } \\
\text { package list? Instead of nothing, } \\
\text { the package is fine as well. } \\
\text { Whatever you give. I accept it with } \\
\text { sincerity, rabbi. (Pg 269) } \\
\text { 2. I doubtfully welcome his helping } \\
\text { hand. He swung his grip twice with } \\
\text { a faint smile. (Pg 284) } \\
\text { 3. "In fact, we should be proud to } \\
\text { have a teacher like him," I } \\
\text { whispered to Dulmajid who was } \\
\text { always sedated by Kiyai Rais' words. } \\
\text { (Pg 291) } \\
\text { 4. "We are sincere to educate you and } \\
\text { you are sincere to be willing to } \\
\text { educate." (P. 295) }\end{array}$ \\
\hline
\end{tabular}

\subsection{Religious Values in Negeri Lima Menara Novel by A. Fuadi}

The researcher will describe the religious values in the "Negeri Lima Menara" novel by A. Fuadi, which is presented in tabular form consisting of 6 categories, namely in the following table: 
Tabel. 3 Religious Values

\begin{tabular}{|c|c|c|c|c|}
\hline \multirow{2}{*}{ No. } & \multirow{2}{*}{ Religious Values } & \multirow{2}{*}{ No Novel Pages } & \multicolumn{2}{|c|}{ Total } \\
\hline & & & Freq & $\%$ \\
\hline 1. & Submission and obedience & $11,14,52,55,137,179,141$ & 7 & 24,137 \\
\hline 2. & A life full of glory & $\begin{array}{c}144,190,197,253 \\
274,362,157\end{array}$ & 7 & 24,137 \\
\hline 3. & $\begin{array}{l}\text { The inner feeling that has to } \\
\text { do with God }\end{array}$ & $181,298,367,404,405$ & 5 & 17,241 \\
\hline 4. & Feelings of sin & $81,142,363,368,397$ & 5 & 17,241 \\
\hline 5. & Fear & 368,397 & 2 & 6,896 \\
\hline 6. & $\begin{array}{l}\text { Recognizing the greatness of } \\
\text { God }\end{array}$ & $296,297,177,197,310$ & 5 & 17,241 \\
\hline \multicolumn{3}{|c|}{ TOTAL } & 29 & $100 \%$ \\
\hline
\end{tabular}

Table 3 above shows that in the Negeri Lima Menara Novel, there are 29 religious values which are divided into 6 aspects, namely 7 pieces of self-submission and obedience $(24.137 \%), 7$ lives of benevolence $(24.137 \%)$, inner feelings that have a connection with 5 pieces of God (17.241\%), 5 pieces of guilt feelings $(17.241 \%)$, feelings of fear $(6.896 \%)$, acknowledging the greatness of God 5 pieces (17.241\%). Then the research results are described by describing the religious value of the novel in tabular form, namely:

Tabel 4. Religious Values in Negeri Lima Menara Novel By A. Fuadi

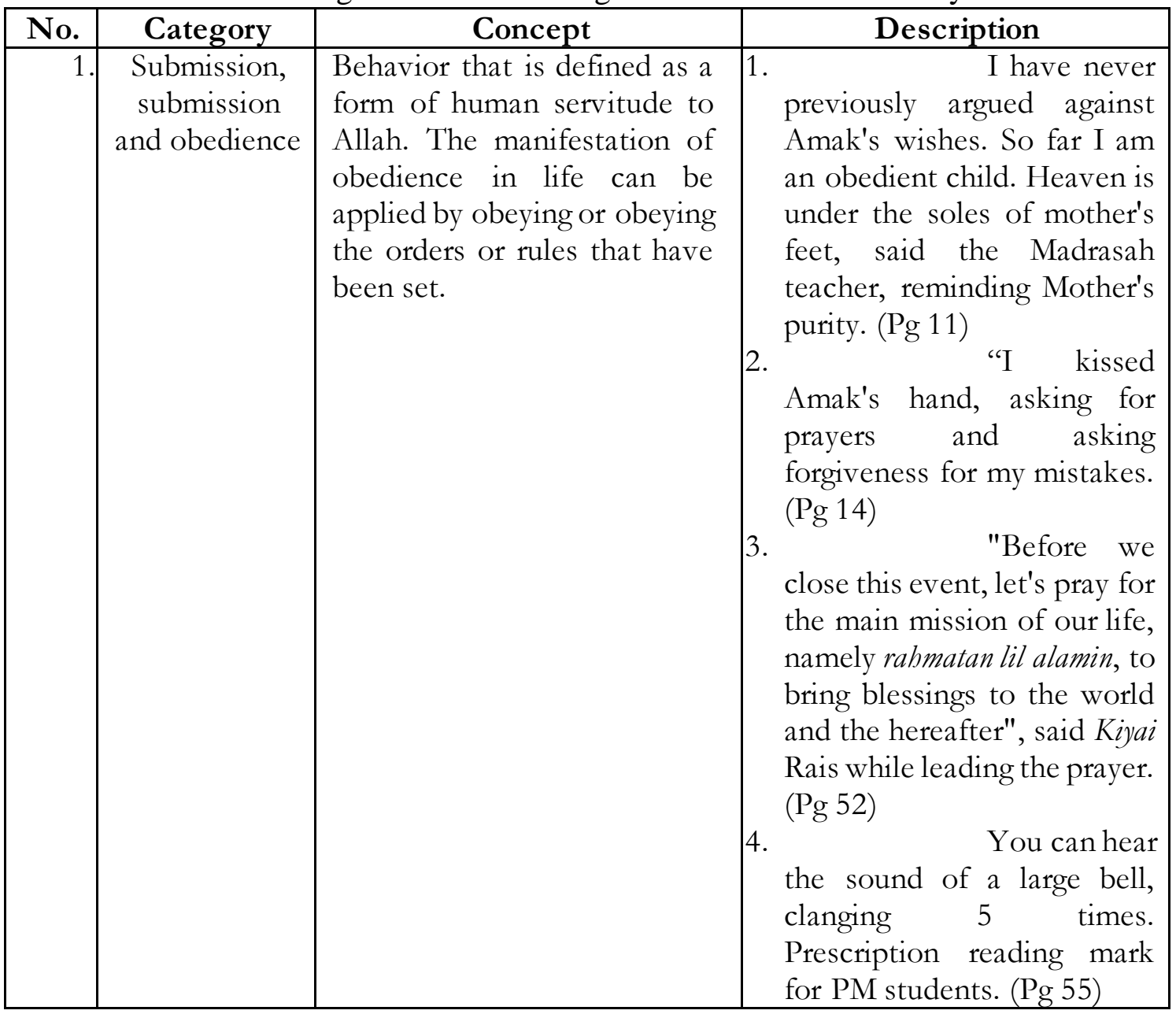




\begin{tabular}{|c|c|c|c|}
\hline & & & $\begin{array}{l}\text { 5. "Are my } \\
\text { friends who were playing and } \\
\text { fighting earlier Muslims?" } \\
\text { asked Amak softly. I nodded } \\
\text { while pursed my lips. } \\
\text { Frowning. "What is the } \\
\text { order of our prophet to } \\
\text { fellow Muslims?" greeting. } \\
\text { "Another?". Smile. } \\
\text { "Another?". Brothers. "Well, } \\
\text { the siblings are friends, don't } \\
\text { fight, they love each other. } \\
\text { That's the prophet's order. } \\
\text { Want to follow the prophet } \\
\text { ?. Want". (Pg 137) } \\
\text { "Bang, ambo } \\
\text { wants to be fair, and justice } \\
\text { must start with yourself, } \\
\text { even from your own } \\
\text { children. (Pg 139) } \\
\text { 7. Never } \\
\text { mention harsh words to } \\
\text { parents. The two of them } \\
\text { are your important place of } \\
\text { devotion in the world. (Pg } \\
\text { 141) }\end{array}$ \\
\hline 1. & Glorious life & $\begin{array}{l}\text { According to KBBI, noble is } \\
\text { high (position, rank, dignity), } \\
\text { namely Believing is the belief } \\
\text { of the heart, not only the } \\
\text { utterance of the tongue, "Faith } \\
\text { is a firm belief that is not } \\
\text { based on doubts that God } \\
\text { exists. }\end{array}$ & $\begin{array}{l}\text { 1. It felt like He heard my } \\
\text { complaint. Sinner's } \\
\text { complaint that there is no } \\
\text { other place to complain than } \\
\text { to Him. (Pg 144) } \\
\text { 2. "My children, knowledge is } \\
\text { like Nur or light. And the } \\
\text { light can't come and it's in a } \\
\text { dark place. Because of that, } \\
\text { clean your heart and head, } \\
\text { so that light can come, touch } \\
\text { and illuminate the hearts of } \\
\text { all of you, "Kiyai Rais started } \\
\text { his discourse gently. lahat. } \\
\text { (Pg 190) } \\
\text { 3. "... Even if he dies in the } \\
\text { process of seeking } \\
\text { knowledge, he will be } \\
\text { rewarded with the title of } \\
\text { martyrdom, and will be } \\
\text { entitled to the premium-um } \\
\text { degree in the hereafter." (Pg } \\
\text { 190) } \\
\text { 4. "Oh... Allah, my servant }\end{array}$ \\
\hline
\end{tabular}




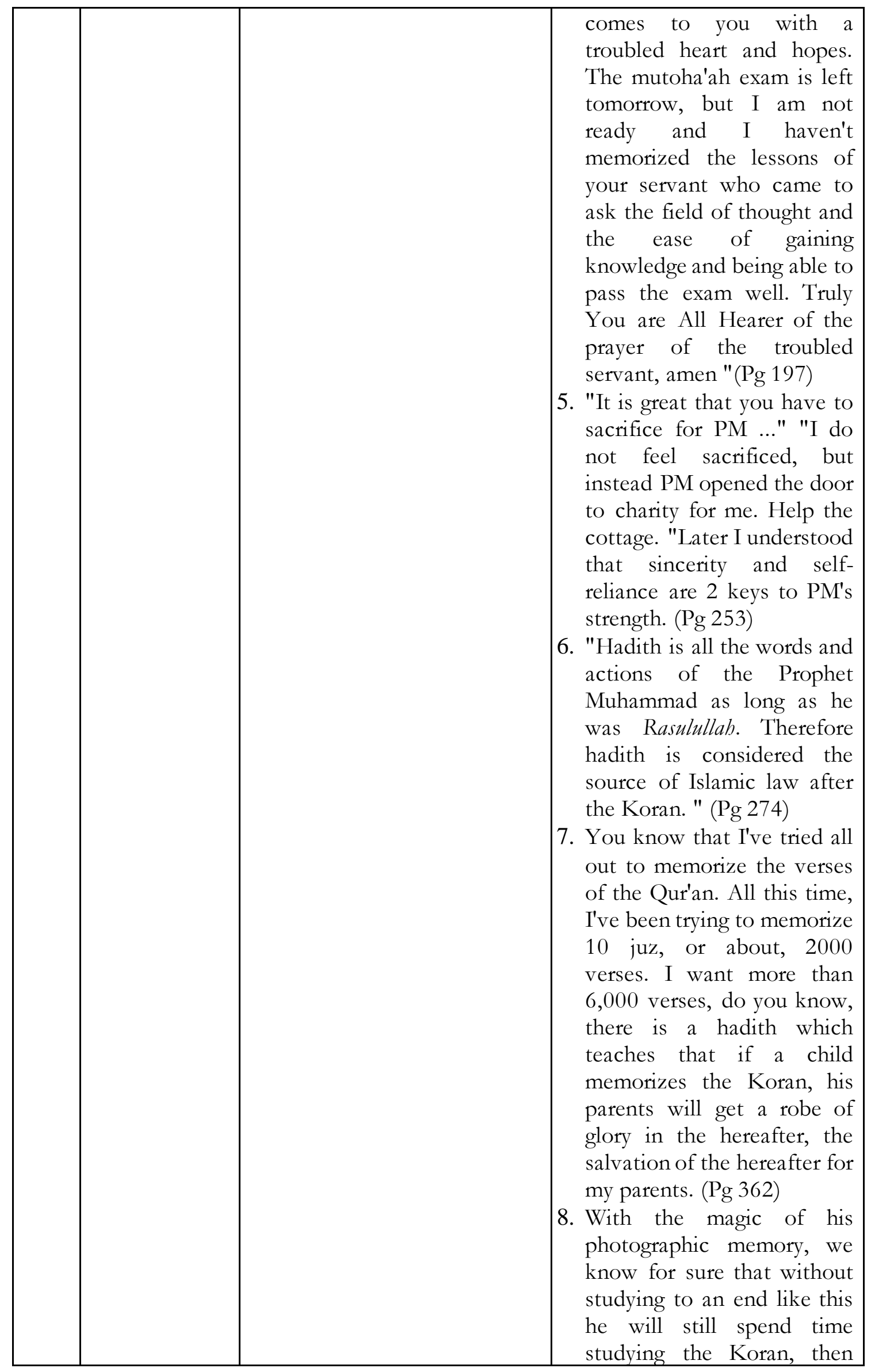




\begin{tabular}{|c|c|c|c|}
\hline & & & $\begin{array}{l}\text { studying the Koran-prayer. } \\
\text { (Pg 357) }\end{array}$ \\
\hline 2. & $\begin{array}{l}\text { Inner feelings } \\
\text { that have to } \\
\text { do with God }\end{array}$ & $\begin{array}{l}\text { Behaviors related to how we } \\
\text { manage feelings. The solution } \\
\text { to not being restless (peace of } \\
\text { mind) is doing zikerullah } \\
\text { (remembering Allah). Kind of } \\
\text { prejudice or positive thinking } \\
\text { to yourself and others and } \\
\text { God. An act of confidence and } \\
\text { courage. }\end{array}$ & $\begin{array}{l}\text { 1. "Remember friends, our } \\
\text { motto: Man jadda wajadda. } \\
\text { Plus prayers from you and } \\
\text { prejudice to God, anything } \\
\text { can happen. (Pg 181) } \\
\text { 2. ".. A busy and time- } \\
\text { consuming job. It's no } \\
\text { wonder that sometimes the } \\
\text { principal is too busy } \\
\text { dedicating his mind time to } \\
\text { the members and misses } \\
\text { studying. This is where } \\
\text { sincerity and leadership are } \\
\text { joined to make ourselves a } \\
\text { leader. " (Pg 298) } \\
\text { 3. "If Allah allows, we will } \\
\text { meet again at a time and in a } \\
\text { place that has been arranged } \\
\text { by Him!" he shouted, } \\
\text { waving. (Pg 367) } \\
\text { 4. "Who knows, we are joking } \\
\text { under the tower, trying to } \\
\text { paint the sky with our } \\
\text { imaginations to explore the } \\
\text { world and create a treasure } \\
\text { trove of knowledge, Allah } \\
\text { will hear and miraculously } \\
\text { treat it." (Pg 404) } \\
\text { 5. The six of us have been in } 5 \\
\text { different countries. In the } \\
\text { five towers of our dreams. } \\
\text { Do not ever underestimate a } \\
\text { dream, no matter how high } \\
\text { it is. God is truly All } \\
\text { Hearing. (Pg 405) }\end{array}$ \\
\hline 3. & Feelings of Sin & $\begin{array}{l}\text { Actions taken based on } \\
\text { predetermined conditions. } \\
\text { Knowledge, namely behavior } \\
\text { in accordance with the rules } \\
\text { that have been set because of a } \\
\text { sense of responsibility to obey } \\
\text { the rules and faith in God. }\end{array}$ & $\begin{array}{l}\text { 1. "... But I thought, it would } \\
\text { be unfair for them to carry } \\
\text { out a portion of the } \\
\text { punishment that I accept. } \\
\text { Personal mistakes must be } \\
\text { paid separately"(Pg } 81) \\
\text { 2. I suddenly became a selfish } \\
\text { person who was black and } \\
\text { very sinful to Amak. } \\
\text { Moreover, I also feel guilty } \\
\text { to Allah for not obeying } \\
\text { Birrul Walidain's orders. (Pg } \\
\text { 142) }\end{array}$ \\
\hline
\end{tabular}




\begin{tabular}{|c|c|c|c|}
\hline & & & $\begin{array}{l}\text { 3. "We approached and } \\
\text { hugged his shoulders. In my } \\
\text { heart I promised to help him } \\
\text { as much as possible. Baso } \\
\text { nodded thankfully while } \\
\text { blowing his nose which was } \\
\text { choked with grief. Suddenly } \\
\text { my nose was also running } \\
\text { like a cold person." (Pg 363) }\end{array}$ \\
\hline 4. & Fear & $\begin{array}{l}\text { According to KBBI, fear is the } \\
\text { feeling of shaking (horror) in } \\
\text { facing something that is } \\
\text { considered to be catastrophic. } \\
\text { Namely, the act of feeling } \\
\text { restless, worried about } \\
\text { breaking the established rules } \\
\text { and regulations. }\end{array}$ & $\begin{array}{l}\text { 1. "... I feel like we all just } \\
\text { realized how painful it is to } \\
\text { lose friends. We are like jaws } \\
\text { missing a molar tooth "(p. } \\
\text { 368) } \\
\text { 2. "My son, have a good fight. } \\
\text { Live once, live that means, } \\
\text { "he whispered into my ear. I } \\
\text { can only say, "Please bless } \\
\text { Mr. Kiyai, thank you for all } \\
\text { your sincerity". I bit my lip, } \\
\text { which began to tremble, } \\
\text { touched by the hug of the } \\
\text { teacher who was so dying. } \\
\text { (Pg 397) }\end{array}$ \\
\hline 5. & $\begin{array}{l}\text { Acknowledgin } \\
g \text { the } \\
\text { Greatness of } \\
\text { God }\end{array}$ & $\begin{array}{l}\text { Acknowledgment the } \\
\text { Greatness of God }\end{array}$ & $\begin{array}{l}\text { 1. "The spirit of sincerity is } \\
\text { displayed every day at PM. } \\
\text { Our wonderful and beloved } \\
\text { teachers receive absolutely } \\
\text { no salary to teach. They all } \\
\text { live in the PM and are given } \\
\text { sufficient living facilities, but } \\
\text { there is no salary. With no } \\
\text { salary expectations from the } \\
\text { start, their intention was to } \\
\text { become Khalis. Teaching is } \\
\text { only because of worship, } \\
\text { because of God's } \\
\text { commands. " (Pg 296-297) } \\
\text { 2. I myself am very curious } \\
\text { about this country called the } \\
\text { United States of America. } \\
\text { He said it was full of Jews } \\
\text { and non-believers, but how } \\
\text { come there are mosques and } \\
\text { Muslims there. Once upon a } \\
\text { time, God willing, I want to } \\
\text { see it directly. Duh, God } \\
\text { Almighty, I'm sure You } \\
\text { heard the voice of my heart. } \\
\text { Can I go there?. (Pg 177) }\end{array}$ \\
\hline
\end{tabular}




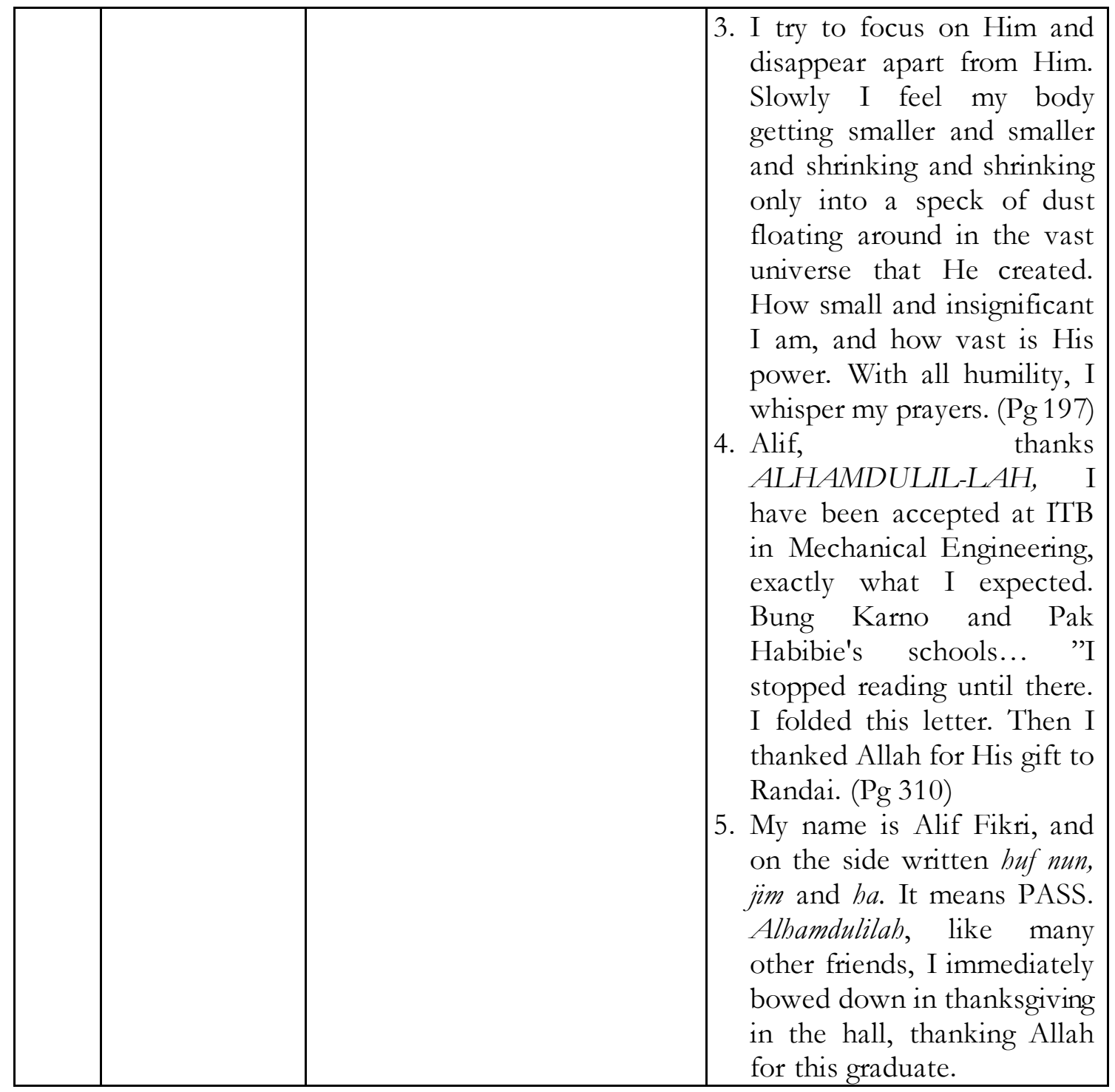

Another thing that strengthens this research is the existence of extrinsic and intrinsic elements which are a means of conveying moral and religious values in the Negeri Lima Menara novel as follows:

1. The extrinsic element tells the life of a pesantren that teaches religious values. One proof of the sentence is "Manjadda wa Jadda" which means who is serious about achieving success.

2. Intrinsic elements in the Negeri Lima Menara novel, namely

a. The themes used include education, friendship and achieving dreams (dreams).

b. The plot in the novel, which is back and forth at the beginning, is told by the character Alif Fikrih who is in Washington DC. Then the main character reminisces about his time in PM (Pondok Maidani).

c. Characteristics in the Negeri Lima Menara novel, namely:

\begin{tabular}{|c|c|l|}
\hline No & Name & \multicolumn{1}{|c|}{ Character / Description } \\
\hline 1 & Alif Fikri & $\begin{array}{l}\text { The main character, likes English lessons, is good at } \\
\text { writing, obedient, persistent in his business. }\end{array}$ \\
\hline 2 & Father & $\begin{array}{l}\text { The father of the main character, quiet, highly } \\
\text { dedicated. }\end{array}$ \\
\hline No & Name & \multicolumn{1}{|c}{ Character / Description } \\
\hline
\end{tabular}




\begin{tabular}{|c|c|c|}
\hline 3 & Emak & $\begin{array}{l}\text { The mother is the main character, religious, simple, } \\
\text { steadfast, compassionate, high loyalty, elementary } \\
\text { school teacher profession. }\end{array}$ \\
\hline 4 & Kiai Rais & $\begin{array}{l}\text { Caregiver as well as the most influential figure and } \\
\text { role model in PM, motivator, fatherhood. }\end{array}$ \\
\hline 5 & Etek Gindo & $\begin{array}{l}\text { The main character's uncle, who lives in Egypt, } \\
\text { provides a solution to entering the Prime Minister } \\
\text { when the main character hesitates because his parents } \\
\text { object to enter high school. }\end{array}$ \\
\hline 6 & Dulmajid & $\begin{array}{l}\text { One of Alif's friends, aspires to build an educational } \\
\text { institution in his hometown, Madura, and make } \\
\text { changes for the better. }\end{array}$ \\
\hline 7 & Said & $\begin{array}{l}\text { One of Alif's close friends, a figure who is always a } \\
\text { leader, is friendly, with Dulmajid } \\
\text { Aspire to build educational institutions. }\end{array}$ \\
\hline 8 & Baso & $\begin{array}{l}\text { Alif's close friend, aspiring to continue studying in } \\
\text { Medina and memorizing Al-Quran as a gift for } \\
\text { parents who have died, is smart. }\end{array}$ \\
\hline 9 & Raja & $\begin{array}{l}\text { One of Alif's close friends, smart, passionate about } \\
\text { mastering all the knowledge taught at PM. }\end{array}$ \\
\hline 10 & Atang & $\begin{array}{l}\text { One of Alif's close friends, who comes from the city } \\
\text { of Bandung, likes theater }\end{array}$ \\
\hline 11 & $\begin{array}{c}\text { Tyson or Rajab } \\
\text { Sujai } \\
\end{array}$ & $\begin{array}{l}\text { The security officer, disciplinarian at the PM, is firm, } \\
\text { sportsmanship. }\end{array}$ \\
\hline 12 & Randai & $\begin{array}{l}\text { Alif's close friend and rival from MTs, both the } \\
\text { trigger and the hindrance to Alif's learning activities at } \\
\text { PM. }\end{array}$ \\
\hline 13 & Ustadz Salman & $\begin{array}{l}\text { Teacher at PM, person in charge of bi-monthly } \\
\text { bulletin and flash } 70 \text { in PM, innovative, motivator. }\end{array}$ \\
\hline 14 & Ustadz Khalid & $\begin{array}{l}\text { One of the teachers at PM, teaches meaning } \\
\text { sincerity to serve religion and education. }\end{array}$ \\
\hline 15 & Ustadz Toriq & $\begin{array}{l}\text { The tutor at PM, responsible for cottage security, was } \\
\text { strict and very consistent }\end{array}$ \\
\hline 16 & Kak Iskandar & $\begin{array}{l}\text { Alif's older brother, captain of the soccer club and } \\
\text { coach. }\end{array}$ \\
\hline
\end{tabular}

d. The setting for this novel is Pondok Madani, Gontor, Ponorogo, East Java, and 2003, when the main character remembers past experiences after graduating from MTs.

e. The point of view that the writer uses is the first person perspective, because the main character always refers to himself with the word I.

f. The language style used by the writer is quite communicative but not excessive and interesting to read full of aphorisms but also funny so it is not boring.

\section{Conclusion}

The moral values in the Negeri Lima Menara novel consist of 6 categories, namely honesty, authentic values, willingness to be responsible, moral independence, moral courage and humility. Meanwhile, the religious values are surrender, submission and obedience, a life 
of glory, inner feelings that have something to do with it. with God, feeling guilty, feeling afraid and acknowledging the greatness of God.

The author conducted an interview with a teacher who teaches Indonesian subjects at Madrasah Aliyah Aisyiyah Medan, namely Mrs. Sri Wahyuni, S.Pd said that the moral and religious values in the "Negeri Lima Menara" novel by A. Fuadi are relevant to be used as literary reading material in MA or SMA and, because the novel also contains moral values such as honesty, authentic values, responsibility, independence, courage and humility. Meanwhile, the religious value contained in this novel really gives readers a lesson in the morning to obey and obey orders, a calm mind, a feeling of fear of sin, acknowledging the greatness of God's power. As well as teaching good moral values and can be used as lesson material in character education and mandate lessons in novels that also have language that is easy to understand. Besides that, the theme of the story is enough to attract students to read it.

Then, the second resource person, Mrs. Ermiza, S.Pd, revealed that the moral and religious values that exist in Negeri Lima Menara Novel are relevant to be used as reading material in MA or SMA and equivalent. Because it has a positive effect on the reader because in the novel there are moral and religious messages which are good examples for character building students. And it can be used as reading material because it attracts students' interest in reading and has a language that is easy to understand and students can get to know the culture in Indonesia as well. After the author distributes questionnaires to 20 students who have read the Negeri Lima Menara novel it can be used as alternative reading material for add insight into literary appreciation, entertain, motivate and can be a good role model as well as straightforward language and storylines that are easy for students to understand.

\section{References}

Ardiansyah, Novrizal dkk, 2018 "Analisis Nilai Religius Dalam Flim Negeri 5 Menara Yang diadaptasi Dari Novel AhmadFuadi”, Jurnal Vol.1 No.5, September 2018 P - ISSN 2614624X E - ISSN 2614-6231.

Arikunto, Suharsimi, dkk. 2015. Penelitian Tindakan Kelas. Jakarta. PT. Bumi Aksara. 2002. Penelitian Tindakan Kelas. Jakarta. PT. Bumi Aksara.

Astuti, W.W., Daulay, M.A., Gafary, D.M. (2019). Indication of Moral Erosion in Children's Fiction. Britain International of Linguistics, Arts andEducation (BIoLAE) Journal Vol.1 (2): $42-50$.

Atmusuwito, S. 1989. Perhal Sastra dan Religiusitas dalam Sastra. Bandung. Sinar Baru

Bertens, K. 2007. Etika. Jakarta. PT. Gramedia Pustaka Utama.

Cahyono, Bambang Yudi. 1995. Kristal-kristal Ilmu Bahasa. Surabaya: Airlangga University Press.

Daroeso, Bambang. 1986. Dasar dan Konsep Pendidikan Moral. Semarang: Aneka Ilmu.

Fuadi, A. 2009. Novel "Negeri Lima Menara”, Jakarta. PT. Gramedia Pustaka Utama.

GUSAL, L. O. 2017. Nilai-nilai Pendidikan dalam Cerita Rakyat Sulawesi Tenggara Karya Laode Sidu. Jurnal Humanika 3 (15).

Haidir, JP, D., and Idayani, E. (2020). Implementation of Moral Values in Scouts (Study on Madrasah Ibtidaiyah State 1 Medan). Budapest International Research and Critics Institute-Journal (BIRCI-Journal) Vol 3 (2): 1403-1412.

Hari Nuggraha, Fajar Britanta, 2014 "Nilai Moral Dalam Novel Pulang Karya Laila S Chudori". Skripsi tidak diterbitkan. Universitas Negeri Yogyakarta. Yogyakarta.

Hidayah, Nur Kholis, dkk. "Nilai-nilai dalam Novel Negeri Lima Menara Karya A. Fuadi". Jurnal tida diterbitkan. Universitas Negeri Malang. Malang. 
Iskandar, 2013. Metodelogi Penelitian Pendidikan dan Sosial. Jakarta: Reverensi.

KBBI offline 1.3,http://ebsoft.web.id, Diakses 9 Mei 2019

Kasim, Miranti Andi. 2005. "Mengkaji Representasi Nilai-nilai Religius Pengarang dalam Novel The

Da Vinci Code". Jakarta: Encyclopedia of religion. Vol 11 Nomor 2 tahun 2005.Hal

115.http:// ejournal.Undiksha. Diakses 3 Maret 2019 Pukul 11.30 WIB.

Kusumawati, Yulia. 2013. "Nilai-Nilai Religiositas Novel Moga Bunda Disayang Allah karya Tere Liye dan Skenario Pembelajarannya Di SMA Kelas XI". Skripsi. Universitas Muhammadiyah Purworejo, Purworejo.

Mangunwijaya,Y.B. 1988. Sastra dan Religiositas. Yogyakarta: Sinar Harapan.

Moleong, L.J. 2005. Metodologi Penelitian Kualitatif. Bandung:Remaja Rosdakarya.

Mubin, Minahul. 2013. Religiusitas Tokoh-Tokoh Dalam Novel Bumi Cinta Karya HabiburrahmanElShirazy. Lamongan: Akademika. Vol 8 Nomor 2 tahun 2014. Hal 205. http: // download. Portalgaruda.org. Diakses 3 Maret 2019 Pukul 11.00 WIB.

Nurgiantoro, Burhan. 2007. Teori Pengakajian Fiksi. Yogyakarta: Gajah Mada. University Press.

Poespoprodjo, W. 1986. Filsafat Moral: Kesusilaan dalam Teori dan Praktek. Bandung: Remaja Karya.

Poedjawijatna. 1982. Etika: Filsafat Tingkah Lau. Jakarta: PT. Bina Aksara.

Rusdiana, H. A dkk. 2014. Sistem Informasi Manajemen. Bandung: Pustaka Setia.

Semi, Atar.1993. Metode Penelitian Sastra. Bandung: Angkasa.

Setyawati, Elyna. 2013. "Analisis Nilai Moral Dalam Novel Surat Kecil Untuk Tuhan Karya Agnes

Davonar (Pendekatan Pragmatik)". Skripsi tidak diterbitkan. Universitas Negeri Yogyakarta,Yogyakarta.

Sugiono, 2015. Metode Penelitian Pendidikan (Pendekatan Kuantitatif, Kualitatif, dan R\&D). Bandung: Alfabeta.

Suparlan, 2010. Pendidikan Karakter: Sedemikian Pentingkah dan Apa Yang harus Kita Lakukan, (Online),http://www.suparlan.com, Diakses 6 Maret 2019 Pukul 10.00 WIB.

Suseno, F. M. 1984. Etika Dasar: Masalah-masalah Pokok Filsafat Moral. Yogyakarta: Kanisius. . Etika Jawa: Sebuah Analisa Filsafat tentang Kebojaksanaan Hidup Jawa. Jakarta: PT. Gramedia Pustaka Utama.

Thontowi, A. 2012. Hakekat Religiusitas. (Online),http://www.sumsel.kemenag.go.id, Diakses 6 Maret 2019 Pukul 11.20 WIB.

Uhi, Jannes Alexander. 2016. Filsafat Kebudayaan. Yogyakarta: Pustaka Pelajar.

Utami Putri, Iska Wahyu., 2017 "Analisis Nilai Religius Dalam Novel Antara Cinta Dan Ridha Ummi Karya Asma Nadia Dan Rencana Pelaksanaan Pembelajarannya Di SMA”. Skripsi tidak diterbitkan. Universitas Muhammadiyah Purworejo, Purworejo.

Zakiyah, Qiki Yuliati dan H. A. Rusdiana. 2014. Sistem Informasi Manajemen, Bandung: Pustaka Setia.

Zubair, A. C. 1987. Kuliab Etika. Jakarta: Rajawali Press. 